\title{
Carry-over of mRNA during nuclear transfer in pigs
}

\author{
TW Parry, RS Prather* \\ 162, Animal Science Research Center, Department of Animal Science, \\ University of Missouri-Columbia, Columbia, MO 65211, USA
}

(Received 3 October 1994; accepted 8 March 1995)

\begin{abstract}
Summary - This research was designed to evaluate the changes that might occur to protein production after nuclear transfer. Eight-cell stage pig embryo nuclei were transferred to enucleated metaphase II oocytes. Twelve hours after nuclear transfer the nuclear transfer embryos were labeled with L-[35S] methionine and subjected to 1-dimensional polyacrylamide gel electrophoresis. During normal pig embryo development, embryonic RNA is produced by the 4-cell stage and results in the production of a $51 \mathrm{kDa}$ band. This $51 \mathrm{kDa}$ band persists through the 8-cell and compact morula stages. Eight-cell stage blastomeres of reconstituted embryos continued the production of the $51 \mathrm{kDa}$ band even after treatment with $\alpha$-amanitin. Since $\alpha$-amanitin should block new mRNA synthesis, the production of this $51 \mathrm{kDa}$ band is likely the result of a carry-over of mRNA coding for this protein in the blastomere cytoplasm.
\end{abstract}

\section{nuclear transfer / cloning / swine / embryo / protein synthesis}

Résumé - Transfert d'ARNm pendant le transfert nucléaire chez le porc. Cette étude a pour but d'évaluer les modifications de synthèse protéique qui peuvent se produire après transfert nucléaire. Des noyaux d'embryons de porc au stade 8 cellules sont transférés à des ovocytes "énucléés" en métaphase II. Douze $h$ après transfert nucléaire, les embryons obtenus sont marqués avec la L-méthionine ${ }^{35} S$ et les protéines analysées par électrophorèse mono-directionnelle sur gel de polyacrylamide. Pendant le développement embryonnaire normal, la synthèse d'ARN au stade 4 cellules aboutit à l'apparition d'une bande protéique de $51 \mathrm{Kd}$. Cette bande persiste pendant les stades 8 cellules et morula compacte. Après transfert nucléaire, les embryons du stade 8 cellules continuent à produire la bande protéique de $51 \mathrm{Kd}$ après traitement par l' $\alpha$-amanitine. Comme cet inhibiteur bloque la synthèse d'ARNm, la production de la bande protéique résulte du transport de l'ARNm correspondant présent dans le cytoplasme du blastomère transféré.

transfert nucléaire / clonage / porc / embryon / synthèse protéique

* Correspondence and reprints 


\section{INTRODUCTION}

Nuclear reprogramming can be described as the event in which a transplanted nucleus is coerced to go through morphological events that it previously completed. Without this reprogramming serious developmental consequences would result (Prather and Robl, 1991). For example, if an 8-cell blastomere was transferred to a recipient enucleated metaphase II oocyte and compaction occurred at the next cell stage, ie the 2-cell stage, too few cells will be present to form a normal embryo. In the mouse such an embryo would fail after implantation because a minimum of $8-16$ cells at compaction is required to form a competent blastocyst, containing both an inner cell mass and a trophoblast (Tarkowski and Wroblewska, 1967). When nuclei are transferred to enucleated oocytes and the early developmental events are recapitulated, it might be concluded that reprogramming occurred. Smith and Wilmut (1989) demonstrated this by transferring inner-cell-mass cells of sheep into recipient enucleated oocytes. They observed early cleavage stages and then compaction, blastocoel formation and development to term. Theoretically, if the nuclei had not been reprogrammed to act as a zygote nucleus, then the conceptus would not have gone to term. Therefore, the presence of blastocyst stage embryos from nuclear transfer procedures at a time coincident with normal development of fertilized embryos indicates that the transplanted nucleus has, to some degree, been reprogrammed (Willadsen, 1986; Prather et al, 1987, 1989a; Stice and Robl, 1988; Young et al, 1991).

In an attempt to begin to study the biochemical events that would be indicative of nuclear reprogramming, we focused on the $51 \mathrm{kDa}$ band produced by the 4-cell stage pig embryo. Sixteen-hours after cleavage to the 4-cell stage RNA polymerase IIdependent RNA synthesis results in the appearance of at least 3 new proteins (26, 42 , and $51 \mathrm{kDa}$ ) (Schoenbeck et al, 1992). The $51 \mathrm{kDa}$ band increases in intensity and became most prominent at $24 \mathrm{~h}$ post-cleavage, and persists into the 8- and 16-cell stage. Thus, we wanted to test whether the $51 \mathrm{kDa}$ band would disappear after a blastomere from an 8-cell stage embryo was transferred to an enucleated metaphase II oocyte.

\section{MATERIALS AND METHODS}

\section{Oocyte collection and selection}

Ovaries were collected and transported from a commercial slaughterhouse to the lab at $39^{\circ} \mathrm{C}$. Follicles 3-6 mm in diameter were aspirated from oocytes and then rinsed in TL Hepes (Prather et al, 1989a) supplemented with $0.3 \%$ BSA. Oocytes with a uniform cytoplasm and a thick complete cumulus cell mass were selected and matured in Waymouth MB 752/1 (Sigma Chemical Co, Saint Louis, MO) supplemented with $10 \%$ fetal calf serum, $10 \%$ follicular fluid, $10 \mathrm{IU} / \mathrm{ml}$ PMSG and $10 \mathrm{IU} / \mathrm{ml} \mathrm{hCG}$ for $20 \mathrm{~h}$, and then in hormonefree Waymouth medium for $24 \mathrm{~h}$ (Funahashi and Day, 1993). Fifty microliter drops of medium were placed in polystyrene culture dishes (Becton Dickinson Labware, Oxnard, CA), and overlaid with paraffin oil that had been pre-equilibrated in Whitten's medium salts and sterilized. Maturation occurred at $39^{\circ} \mathrm{C}$ in a humidified atmosphere of $5 \% \mathrm{CO}_{2}$ in air with 10 oocytes per drop of medium.

\section{Embryo collection}

Crossbred gilts were monitored for estrus twice a day, and inseminated at 12 and $24 \mathrm{~h}$ post-estrus detection. Four days after estrus detection, gilts were anesthetized and a midventral laparotomy was performed to exteriorize the reproductive tract. The oviducts and uterus were flushed retrograde with TL Hepes. Embryos were then recovered and placed in $50 \mu \mathrm{l}$ of TL Hepes and placed in a $39^{\circ} \mathrm{C}$ incubator with a humidified air atmosphere until manipulation. 


\section{Manipulation}

Nuclear transfer was conducted as described by Prather et al (1989a). Eight-cell stage embryos and unfertilized recipient oocytes were treated with cytoskeltal inhibitors $(7.5 \mu \mathrm{g} / \mathrm{ml}$ cytochalasin $B$ and $0.1 \mu \mathrm{g} / \mathrm{ml}$ demecolcine; Sigma, Saint Louis) and the DNA-specific fluorescent dye bisbenzimide ( $2 \mu \mathrm{g} / \mathrm{ml}$, Sigma). The recipient oocyte was flashed with ultraviolet light in order to locate the metaphase chromosomes; a micropipette was then inserted into the oocyte, and the metaphase chromosomes were removed with a portion of membrane-bound cytoplasm. One blastomere from the donor embryo was inserted in the perivitelline space, against the plasma membrane of the enucleated metaphase II oocyte. The nuclear transfer embryo was then exposed to $5 \mathrm{~V} / \mathrm{mm}$ $\mathrm{AC}$ for $10 \mathrm{~s}$, followed by $120 \mathrm{~V} / \mathrm{mm} \mathrm{DC}$ for $30 \mu \mathrm{s}$ in electroporation medium ( $0.3 \mathrm{M}$ mannitol $+5 \%$ TL Hepes: Prather et al, 1991). This both activated the oocyte and induced cell-cell fusion. Thirty minutes post-electrostimulation, samples were evaluated for fusion or non-fusion.

\section{Culture and radiolabeling}

Embryos, oocytes and nuclear transfer embryos were cultured in TL Hepes (Experiment 1) or TL Hepes containing $20 \mu \mathrm{g} / \mathrm{ml} \alpha$-amanitin (Experiment 2) in a humidified atmosphere of air at $39^{\circ} \mathrm{C}$ for $12 \mathrm{~h}$, then were placed in $26 \mu \mathrm{l}$ of TL Hepes containing $3 \mu \mathrm{L}$-[ $\left.{ }^{35} \mathrm{~S}\right]$ methionine (Du Pont Company, Wilmington, DE) for $3.5 \mathrm{~h}$. The samples were then rinsed through six $50 \mu \mathrm{l}$ drops of nonradioactive TL Hepes with a final rinse in phosphate-buffered saline (BSA-Free). Samples were then placed in microcentrifuge tubes with $15 \mu \mathrm{l}$ of SDS lysis buffer and stored at $-80^{\circ} \mathrm{C}$.

\section{Protein profiles}

Radiolabeled samples and prestained molecular mass markers (Rainbow Protein Molecular Weight Markers, Amersham) were boiled for $1 \mathrm{~min}$. Samples were subjected to 10\% 1-dimensional SDSPAGE and run in parallel with molecular mass markers. After electrophoresis, gels were fixed and treated with a fluorite (En ${ }^{3}$ Hance; New England Nuclear, Boston, MA). Gels were dried under vacuum at $70^{\circ} \mathrm{C}$ for about $1 \mathrm{~h}$, and exposed to Kodak X-OMAT AR film (Eastman Kodak, Rochester, NY) for 2-6 d.

\section{Statistics}

Differences in the presence or absence of the $51 \mathrm{kDa}$ band were evaluated by constructing $95 \%$ confidence intervals about the mean (Snedecor and Cochran, 1980).

\section{RESULTS}

After $12 \mathrm{~h}$, the $51 \mathrm{kDa}$ band was present in all donor 8-cell stage embryos (7/7), while it was not detectable in oocytes $(0 / 7)$ or enucleated oocytes $(0 / 7)$. The $51 \mathrm{kDa}$ band was present in the non-fused nuclear transferred embryos $66 \%(8 / 12)$ of the time, while in the fused nuclear transferred embryos it was present $43 \%(9 / 21)$ of the time $(P>$ 0.05).

Since the $51 \mathrm{kDa}$ band remained even after nuclear transfer, it was decided to block new mRNA synthesis with $\alpha$-amanitin. In the second experiment, embryos were placed in $\alpha$-amanitin after cell fusion. The $51 \mathrm{kDa}$ band could be detected in all of the donor 8-cell stage embryos (8/8) while it was not detectable in the oocytes $(0 / 6)$ or the enucleated oocytes (0/6). Interestingly, the $51 \mathrm{kDa}$ band was still present in the nonfused $(5 / 7)$ as well as the fused $(7 / 7)$ nuclear transfer embryos $(P>0.05)$ (fig 1$)$.

\section{DISCUSSION}

Nuclei from early cleavage stage mammalian embryos other than mouse embryos, have been reprogrammed to behave as a 1-cell embryos by transfer to enucleated activated meioctic metaphase II oocyte (First and Prather, 1991). In efforts to test the idea of reprogramming we placed a blastomere 


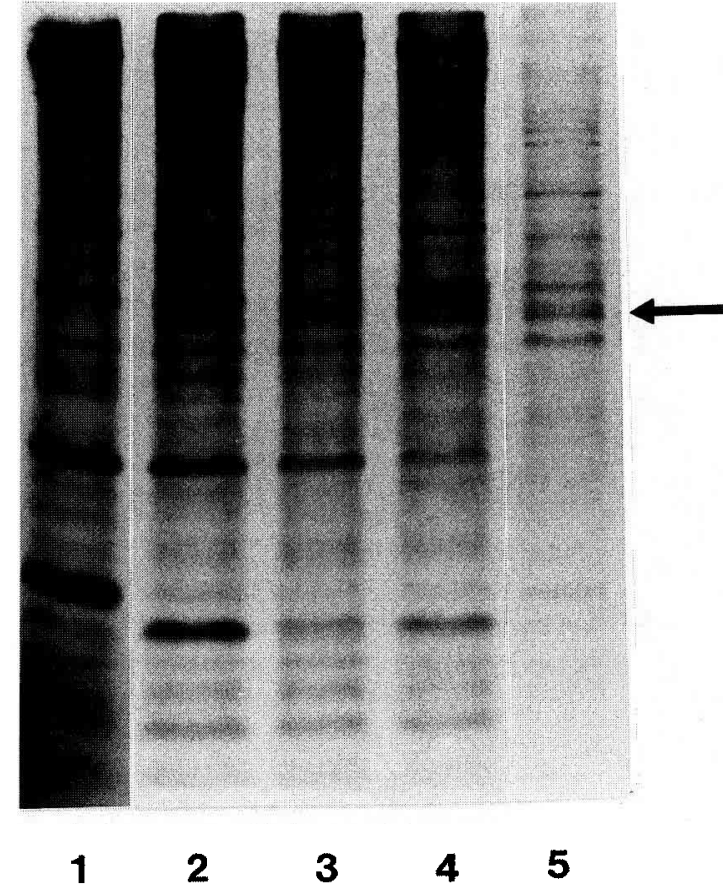

Fig 1. Protein profiles of nuclear transfer and control embryos. Embryos were cultured for $12 \mathrm{~h}$ in the presence of $\alpha$-amanitin and then labeled with $\mathrm{L}-\left[{ }^{35} \mathrm{~S}\right]$ methionine for 3.5 $h$, rinsed and individually lysed. Individual embryos were placed on each lane; lane 1, metaphase II oocyte; lane 2, non-fused nuclear transfer embryo; lanes 3 and 4 , fused nuclear transfer embryo; lane 5, donor 8-cell stage embryo. Arrow denotes the 51 kDa band. from an 8-cell stage embryo in an enucleated metaphase II oocyte and evaluated the protein profiles. Since the late 4-cell stage to blastocyst stage pig embryo produces a $51 \mathrm{kDa}$ band, we hypothesize that the disappearance of this band after nuclear transfer would indicate reprogramming. It was found that half of the fused nuclear transferred embryos were still producing the $51 \mathrm{kDa}$ band, which was not different from the non-fused nuclear transfer embryos. In the next experiment the production of new mRNA was blocked with $\alpha$-amanitin. After culturing the fused nuclear transferred embryos in $\alpha$-amanitin, the $51 \mathrm{kDa}$ band was detected $100 \%$ of the time. While the $51 \mathrm{kDa}$ band was present in all of the nuclear transfer embryos, this was no different from the non-fused controls; a similar relationship held for both experiments. Unfortunately, this did not answer the question of reprogramming but does suggest that there is mRNA carry-over from the cytoplasm of the transferred blastomere. When cell fusion was initially used to facilitate nuclear transfer little concern was given to the possibility of message carry-over. This is the first study clearly demonstrating that a message present in the donor blastomere can result in protein production in the resulting nuclear transfer embryo.

Nuclear remodeling is suggested by previous studies showing an exchange of protein between the cytoplasm of the oocyte to the transferred nucleus and from the transferred nucleus to the cytoplasm of the oocytes (Prather and Robl, 1991). A specific example in the pig of the acquisition of oocyte protein by the transferred nucleus is the nucleus lamins (Prather et al, 1989b), while the release of nuclear protein into the cytoplasm is suggested with the 11 antigen (Prather et al, 1992). This exchange of protein is thought to be responsible for the 
structural remodeling needed for reprogramming the transferred nucleus. Furthermore, results obtained with electron microscopy demonstrate that after nuclear transfer, nucleoli appear morphologically similar to zygotic nucleoli. This suggests that due to the morphologic change the nucleoli of the nuclear transfer embryo are not synthesizing rRNA (Mayes et al, 1994). In addition, data gathered by Prather and Rickords (1992), using a monoclonal antibody to proteins involved in splicing RNA, suggest that RNA processing does not occur immediately after nuclear transfer.

Similar suggestions of reprogramming in other domestic species have been observed with the TEC antigen (Van StekelenburgHamers et al, 1994) as well as the attainment of specific developmental stages after nuclear transfer (reviewed by First and Prather, 1991). Therefore, since we detected the $51 \mathrm{kDa}$ band in the $\alpha$-amanitin-treated fused nuclear transferred embryos, we cannot conclude that nuclear reprogramming had occurred, while we can conclude that there is mRNA carry-over from the donor blastomere. One way to circumvent this carry-over of RNA would be to transfer only the nucleus as in amphibian nuclear transfer (Gurdon and Laskey, 1970). Such a procedure has recently been reported in cattle (Collas and Barnes, 1994), but unfortunately has not dramatically increased the subsequent rates of development. If message carry-over has an affect on the ability of the nuclear transfer embryo to develop, there may actually be an advantage to using donor cells that are more advanced in development, as they would also be smaller in size and possibly contain less RNA to carry-over.

Further studies are needed to evaluate the effects to these messages on development and evaluate specific messages for reprogramming. Such experiments will be much easier to conduct and much more meaningful when the $51 \mathrm{kDa}$ protein(s) is identified and the sequence of the mRNA elucidated. Such knowledge will reduce the problems of identifying maternal, zygotic or carry-over RNA.

\section{ACKNOWLEDGMENTS}

This research was prepared while supported by the Food for the 21st Century, the USDA CSRS (90-37265-5452), and is a contribution from the Missouri Agricultural Experiment Station Journal Series Number 12243.

\section{REFERENCES}

Collas P, Barnes FL (1994) Nuclear transplantation by microinjection of inner celi mass and granulosa cell nuclei. Mol Reprod Dev 38, 264-267

First NL, Prather RS (1991) Genomic potential in mammals. Differentiation $48,1-8$

Funahashi H, Day BN (1993) Effects of the duration of exposure to supplemental hormones on cytoplasmic maturation of pig oocytes in vitro. $J$ Reprod Fertil 98, 179-185

Gurdon JB, Laskey RA (1970) The transplantation of nuclei from single cultured cells into enucleated frogs' eggs. J Embryol Exp Morph 24, 227-248

Mayes MA, Stogsdill PL, Parry TW, Kinden DA, Prather RS (1994) Reprogramming of nucleoli after nuclear transfer of pig blastomeres into enucleated oocytes. Dev Biol 163, 542

Prather RS, Robl JM (1991) Cloning by nuclear transfer and splitting in laboratory and domestic animals. $I n$ : Animal Applications of Research in Mammalian Development (RS Pederson, A McLaren, NL First, eds) The Cold Spring Harbor Laboratory Press, USA, 205-232

Prather RS, Rickords LF (1992) Developmental regulation of a snRNP core protein epitope during pig embryogenesis and after nuclear transfer for cloning. Mol Reprod Dev 33, 119-123

Prather RS, Barnes FL, Sims ML, Robl JM, Eyestone WH, First NL (1987) Nuclear transplantation in the bovine embryo: assessment of donor nuclei and recipient oocyte stage. Biol Reprod 37, 859-866

Prather RS, Sims MM, First NL (1989a) Nuclear transplantation in early pig embryos. Biol Reprod 41,414 418

Prather RS, Sims MM, Maul GG, First NL, Schatten G (1989b) Nuclear lamin antigens are developmentally regulated during porcine and bovine embryogenesis. Biol Reprod 41, 123-132

Prather RS, Eichen PA, Nicks DK, Peters MS (1991) Artificial activation of porcine oocytes matured in vitro. Mol Reprod Dev 28, 405-409 
Prather RS, Stumpf TT, Rickords LF (1992) Reprogramming the nucleus and synchronizing it with the cytoplasm. International Symposium on Cloning Mammals by Nuclear Transplantation, Colorado State University, Fort Collins, CO, USA, 26-27

Schoenbeck RA, Peters MS, Rickords LF, Stumpf $\Pi$, Prather RS (1992) Characterization of DNA synthesis and the transition from maternal to embryonic control in the 4-cell porcine embryo. Biol Reprod 47, 1118-1125

Smith LC, Wilmut I (1989) Influence of nuclear and cytoplasmic activity on the development in vivo of sheep embryos after nuclear transplantation. Biol Reprod 40, 1027-1035

Snedecor GW, Cochran WG (1980) Statistical Methods. lowa State University Press, Ames, IA, USA, Seventh Edition, p 121
Stice SL, Robl JM (1988) Nuclear reprogramming in nuclear transplant rabbit embryos. Biol Reprod 39 , 657-664

Tarkowski AK, Wroblewska J (1967) Development of blastomeres of mouse eggs isolated at the 4- and 8-cell stage. J Embryol Exp Morph 18, 155-180

Van Stekelenburgh-Hamers AEP, Rebel HG, Van Inzen WG et al (1994) Stage-specific appearance of the mouse antigen TEC-3 in normal and nuclear transfer bovine embryos: re-expression after nuclear transfer. Mol Reprod Dev 37, 27-33

Willadsen SM (1986) Nuclear transplantation in sheep embryos. Nature (Lond) 320, 63-65

Yong Z, Jianchen W, Jufen Q, Zhiming H (1991) Nuclear transplantation in goats. Theriogenology 35,299 